\title{
MATURATION AND FERTILIZATION IN VITRO OF GUINEA-PIG OVARIAN OOCYTES
}

\author{
R. YANAGIMACHI \\ Department of Anatomy and Reproductive Biology, \\ University of Hawaii School of Medicine, Honolulu, Hawaii 96822, U.S.A.
}

\section{(Received 10th December 1973)}

Mammalian ovarian oocytes can mature in vitro when liberated from Graafian follicles and placed in appropriate culture media. This was first demonstrated in the rabbit (Pincus \& Enzmann, 1935, 1937; Chang, 1955a, b) and has been confirmed in a variety of animals (see Donahue, 1972; Biggers, 1973; Fowler \& Edwards, 1973).

According to Jagiello (1969), 80 to $100 \%$ of guinea-pig oocytes isolated from ovaries of adult females in the middle (Days 5 to 8 ) of their oestrous cycle resume meiosis upon culture and may reach metaphase II by $14 \mathrm{hr}$ of culture. Unfortunately, Jagiello gave no detailed information of the techniques which she used for isolation and culture of the oocytes and did not determine whether the oocytes matured in vitro were fertilizable. This paper describes a method of culturing guinea-pig oocytes, which yields mature oocytes (ova) capable of fertilization.

The medium used for culture of the oocytes was a mixture of eight parts of TC199 (Hanks' solution base; Difco) and two parts of heat-inactivated fetal calf serum $\left(56^{\circ} \mathrm{C}, 30 \mathrm{~min}\right.$; Gibco), supplemented with $\mathrm{NaHCO}_{3}(2 \mathrm{mg} / \mathrm{ml})$, $\mathrm{K}$-penicillin $\mathrm{G}(100$ units $/ \mathrm{ml})$ and streptomycin sulphate $(50 \mu \mathrm{g} / \mathrm{ml})$. The medium was prepared within a few days before use, sterilized by filtration through a millipore filter, and kept in a refrigerator $\left(4^{\circ} \mathrm{C}\right)$ until use. The $\mathrm{pH}$ of the medium was 7.4 to 7.5 at $37^{\circ} \mathrm{C}$ when equilibrated with $5 \% \mathrm{CO}_{2}$ in air.

Adult female guinea-pigs were examined for the condition of the vagina. Those with a tightly closed vagina were killed and their ovaries were removed. Occasionally, a few females were found to be pregnant when killed, but their ovaries were also found to be suitable for collection of oocytes. The ovaries were placed in a dish containing culture medium and examined under incident light with a stereo-dissecting microscope. Relatively transparent areas on the ovarian surface, which indicated the presence of growing Graafian follicles underneath, were punctured with a sharp stainless-steel needle to release the contents of the follicles. Thus, as many as twenty to thirty oocytes could be recovered from the ovaries of one animal, although the number of oocytes recovered varied considerably from animal to animal. Some of the oocytes recovered showed definite signs of degeneration, such as dispersion of cumulus cells and deterioration of cytoplasm. Other oocytes were surrounded by only a few layers of cumulus cells. Only those oocytes which were surrounded by tightly packed, dense layers of cumulus cells were chosen for culture. These were washed three times with fresh culture medium and placed in 0.5 to $0.8 \mathrm{ml}$ 
of medium under mineral oil in a sterile plastic dish. The number of oocytes in each dish was ten to twenty. Incubation was carried out at $37^{\circ} \mathrm{C}$, for 20 to $24 \mathrm{hr}$, under an atmosphere of $5 \% \mathrm{CO}_{2}$ in air.

When examined before or shortly after the beginning of culture, the oocytes were surrounded by layers of tightly packed cumulus cells (Pl. 1, Figs 1 and 2). The nuclei of these oocytes were in the germinal vesicle stage (Pl. 1, Fig. 3). When examined after 20 to $24 \mathrm{hr}$ of culture, the cumulus cells were loosely arranged around the oocytes (Pl. 1, Fig. 4). These cells, unlike those surrounding the oocytes before culture, could be readily dispersed by hyaluronidase treatment. Apparently, the matrix of the cumulus cells became looser and more susceptible to hyaluronidase during culture.

Of a total of 197 oocytes (eleven exps.) examined between 20 and $24 \mathrm{hr}$ of culture, $128(65 \%)$ had polar bodies (Pl. 1, Fig. 5), $49(25 \%)$ had no polar body and $20(10 \%)$ showed signs of cytoplasmic deterioration. The nuclei of the oocytes with polar bodies were all at metaphase II (Pl. 1, Figs 6 and 7) and those of the oocytes without polar bodies were at metaphase I (Pl. 1, Figs 8 and 9).

In order to determine whether the oocytes cultured in vitro are capable of fertilization, fifty-four oocytes with polar bodies were inseminated in vitro with capacitated guinea-pig spermatozoa, according to the procedures previously described (Yanagimachi, 1972a). In these experiments, all the cumulus cells were removed from the surface of the oocytes by hyaluronidase treatment before insemination. Soon after insemination, many spermatozoa became attached to the surface of the zona pellucida (Pl. 1, Fig. 10). Sperm passage through the zona pellucida was observed in some of the oocytes within $1 \mathrm{hr}$ of insemination (Pl. 1, Fig. 11). Between $1 \frac{1}{2}$ and $2 \mathrm{hr}$ after insemination, forty-seven out of fifty-four oocytes (ova) showed swollen sperm heads within their cytoplasm (Pl. 1, Fig. 12).

\section{EXPLANATION OF PLATE 1}

Figs 1 and 2. Guinea-pig oocytes before culture, surrounded by tightly packed cumulus cells. Fig. 1, $\times 95$; Fig. 2, $\times 250$.

Fig. 3. Germinal vesicle (GV) of an oocyte before culture, fixed for $24 \mathrm{hr}$ in acetic alcohol and stained with aceto-lacmoid. $\times 400$.

Fig. 4. An oocyte after $24 \mathrm{hr}$ of culture, showing a loose arrangement of cumulus cells around the oocyte. $\times 250$.

Fic. 5 . An oocyte after $24 \mathrm{hr}$ of culture. Cumulus cells had been dispersed by hyaluronidase, and one (first) polar body is clearly visible at about 11 o'clock. $\times 250$.

FIG. 6. Same as above, but fixed and stained for demonstration of metaphase II chromosomes $(\mathrm{M} 2) . \mathrm{P}$, the first polar body. $\times 500$.

Fig. 7. Metaphase II chromosomes under high magnification, fixed and stained. $\times 650$. Fig. 8. An oocyte after $24 \mathrm{hr}$ of culture, fixed and stained. There is no polar body, and metaphase I chromosomes (M1) are visible. $\times 250$.

FIG. 9. A polar view of metaphase I chromosomes under a higher magnification, fixed and stained. $\times 650$.

Fig. 10. A mature oocyte 15 min after insemination, surrounded by many spermatozoa attached to the zona pellucida. $\times 250$.

Fig. 11. A spermatozoon crossing the zona pellucida $45 \mathrm{~min}$ after insemination. $\times 650$.

FIG. 12. Sperm head (arrow) swollen within the cytoplasm of an ovum, $1 \frac{1}{2} \mathrm{hr}$ after insemination, fixed and stained. $\times 650$. 

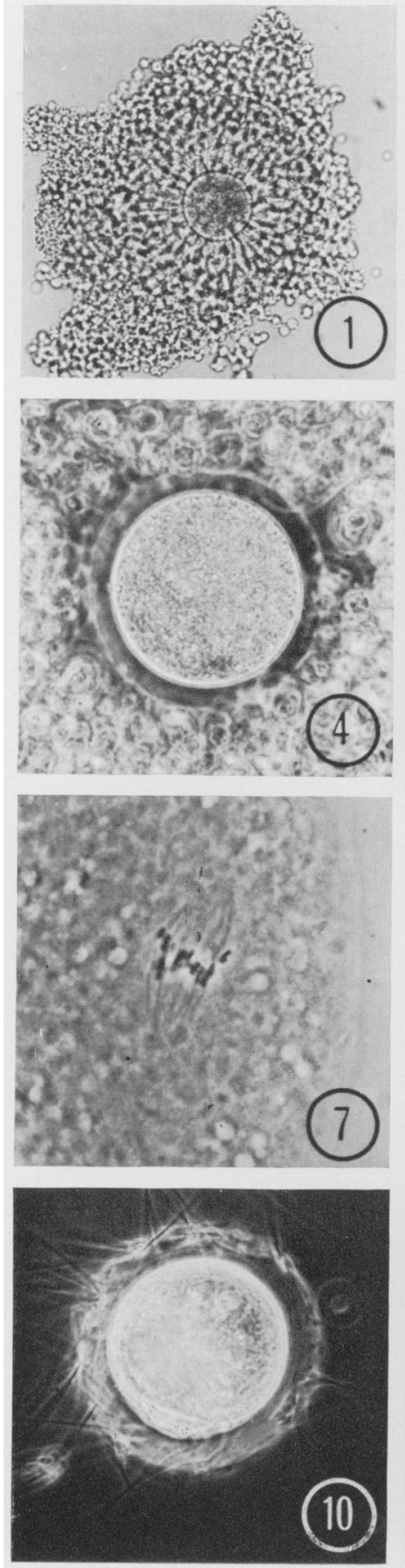
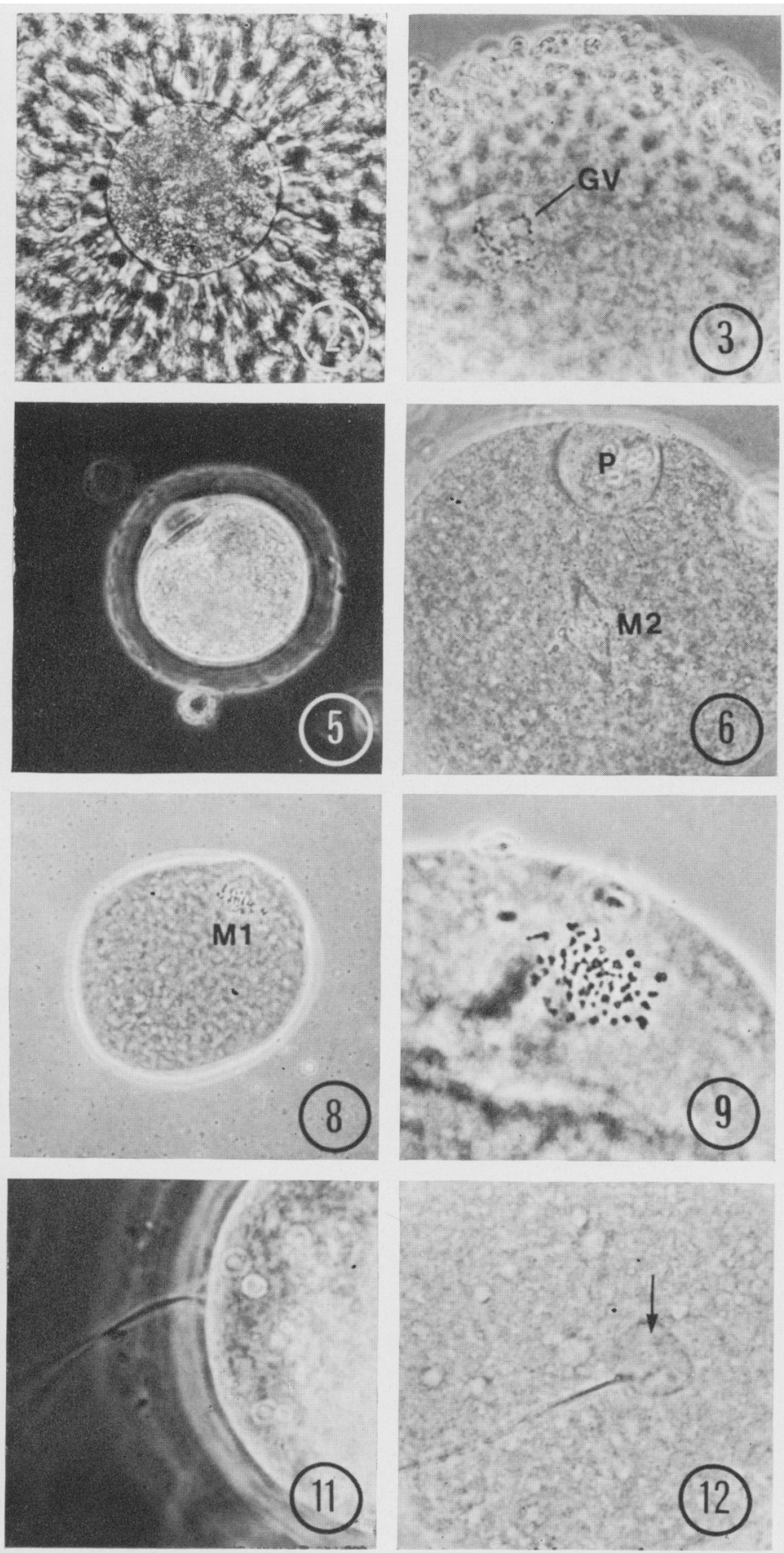
For analytical studies of fertilization in vitro, a reasonably large number of fully mature oocytes is needed. In such laboratory rodents as the rat, mouse and hamster, a large number of freshly ovulated mature ova can be collected from oviducts shortly after superovulation induced by successive injections of animals with FSH (or PMSG) and LH (or HCG). In the guinea-pig, neither precise control of ovulation time nor induction of superovulation has been entirely successful (Dempsey, Hertz \& Young, 1936; Deanesly, 1966; Reed \& Hounslow, 1971). Because of the small numbers of ova naturally ovulated (usually two to four), collection of a large number of mature ova from oviducts at one time is impracticable unless a large colony of guinea-pigs is available. In view of the excellent features of guinea-pig spermatozoa which make them suitable for analytical studies of sperm capacitation (Yanagimachi, 1972a, b) and the need of mature ova for assessment of fertilizability of these spermatozoa, the development of techniques for controlling ovulation time or for induction of superovulation in the guinea-pig is much needed. Until such techniques are developed, naturally ovulated ova must be used for assessment of the fertilizing capacity of spermatozoa. Alternatively, ova matured in vitro (present study) or zona pellucida-free hamster ova (Yanagimachi, 1972c) may, with reasonable precautions, be used as substitutes for naturally ovulated guinea-pig ova, particularly when a large number of ova is needed at the time of the experiment.

According to Thibault \& Gerard (1970) and Thibault (1973), rabbit ovarian oocytes matured in vitro are fully capable of uniting with the spermatozoa. Oocytes are activated by spermatozoa and some of them undergo apparently normal cleavages, but none of them develops into a live fetus. Careful observations have revealed that the sperm head (nucleus) in the ovum cytoplasm does not swell for a considerable period of time and fails to develop into a normal male pronucleus, while the female pronucleus develops quite normally. Thibault \& Gerard (1970) attributed the abnormal behaviour of the sperm nucleus to lack of 'male pronucleus growth factor' in the oocytes matured in vitro. In the guinea-pig oocytes matured in vitro, such a factor is apparently present, since the sperm nucleus can readily swell up after entry into the cytoplasm of these oocytes. This, however, does not necessarily imply that the guinea-pig oocytes matured in vitro are comparable in every physiological aspect with oocytes matured in vivo. Whether the oocytes matured in vitro are fully capable of normal fertilization and development must be the subject of further studies.

This study was supported by grants from the Population Council, the Ford Foundation and U.S. Public Health Service (HD-03402). The author is grateful to Professor C. R. Austin, Dr B. D. Bavister and Mrs C. A. Mahi for their helpful interest and suggestions.

\section{REFERENCES}

Biggers, J. D. (1973) Oogenesis and ovum maturation. In The Regulation of Mammalian Reproduction, Ch. 20, p. 273. Eds. S. J. Segal, R. Crozier and P. A. Corfman. C. C. Thomas, Springfield, Ill. Chang, M. C. (1955a) Fertilization and normal development of follicular oocytes in the rabbit. Science, N.Y. 121, 867. 
Chang, M. C. (1955b) The maturation of rabbit oocytes in culture and their maturation, activation, fertilization and subsequent development in the Fallopian tubes. F. exp. Zool. 128, 379.

Deanesly, R. (1966) The effects of purified lutenizing hormone on the guinea-pig ovary. F. Reprod. Fert. 11, 303.

Dempsey, E. W., Hertz, R. \& Young, W. G. (1936) The experimental induction of oestrus (sexual receptivity) in the normal and ovariectomized guinea pig. Am. F. Physiol. 116, 201.

Donahue, R. P. (1972) The relation of oocyte maturation to ovulation in mammals. In Oogenesis, Ch. 22, p. 413. Eds. J. D. Biggers and A. W. Schuetz. University Park Press, Baltimore.

Fowler, R. E. \& Edwards, R. G. (1973) The genetics of early human development. In Progress in Medical Genetics, Vol. 9, p. 49. Eds. A. G. Steinberg and A. G. Bearn. Grune \& Stratton, New York.

Jagrello, G. M. (1969) Some cytologic aspects of meiosis in female guinea pig. Chromosoma, 27, 95.

Pincus, G. \& Enzmann, E. V. (1935) The comparative behaviour of mammalian eggs in vitro and in vivo. I. The activation of ovarian eggs. J. exp. Med. 62, 665 .

Pincus, G. \& Enzmann, E. V. (1937) The growth, maturation and atresia of ovarian eggs in the rabbit. 7. Morph. 61, 351 .

Reed, M. \& HounsLow, W. F. (1971) Induction of ovulation in the guinea-pig. F. Endocr. 49, 203.

Thibault, C. (1973) In vitro maturation and fertilization of rabbit and cattle oocytes. In The Regulation of Mammalian Reproduction, Ch. 17, p. 231. Eds. S. J. Segal, R. Grozier and P. A. Corfman. C. G. Thomas, Springfield, Ill.

Thibault, C. \& Gerard, M. (1970) Facteur cytoplasmique necessaire à la formation du pronucleus mâle dans l'ovocyte de lapine. C. r. hebd. Séanc. Acad. Sci., Paris, 270, 2025,

Yanagimachi, R. (1972a) Fertilization of guinea pig eggs in vitro. Anat. Rec. 174, 9.

Yanagimachi, R. (1972b) In vitro fertilization of guinea pig ova. Anat. Rec. 172, 430, Abstr.

YanaGimachi, R. (1972c) Penetration of guinea-pig spermatozoa into hamster eggs in vitro. F. Reprod. Fert. 28, 477. 